\title{
PENGEMBANGAN PEMBELAJARAN \\ MULTIMEDIA INTERAKTIF BERBASIS INTERNET PELAJARAN BAHASA INGGRIS
}

\author{
Rita dan Julaga Situmorang \\ SMP Swasta Chandra Kusuma kabupaten Deliserdang dan \\ PPs Universitas Negeri Medan \\ chia6112@gmail.com
}

\begin{abstract}
Abstrak: Tujuan dalam pengembangan ini adalah untuk: menghasilkan media pembelajaran multimedia interaktif berbasis internet pada bahasa inggris memenuhi syarat sebagai media pembelajaran yang baik; dan mengetahui efektivitas penggunaan media pembelajaran multimedia interaktif berbasis internet pada bahasa inggris. Jenis penelitian ini adalah penelitian pengembangan menggunakan model Borg \& Gall dengan model pengembangan pembelajaran Dick \& Carey. Hasil penelitian pengembangan menunjukkan bahwa: uji ahli materi bahasa inggris kualifikasi sangat baik; uji ahli desain pembelajaran kualifikasi sangat baik, uji ahli perangkat lunak kualifikasi sangat baik; uji coba perorangan kualifikasi sangat baik; uji coba kelompok kecil kualifikasi sangat baik; dan uji coba lapangan kualifikasi sangat baik. Kualitas produk menunjukkan bahwa kelompok siswa yang dibelajarkan dengan menggunakan multimedia interaktif berbasis internet lebih tinggi dari kelompok siswa yang dibelajarkan dengan menggunakan media pembelajaran buku teks sebesar.
\end{abstract}

Kata Kunci: pengembangan media pembelajaran multimedia interaktif berbasis internet pada bahasa inggris

\begin{abstract}
The aim of this development is to: generate media interactive multimedia internet-based learning in English qualify as a good medium of learning; and examine the effectiveness of media use internet-based interactive multimedia learning in English. This type of research is the development of research using models Borg \& Gall with instructional development models Dick \& Carey. Development of research results show that: the test materials experts qualified English very well; test instructional design experts excellent qualifications, test software experts excellent qualifications; individual testing excellent qualifications; small group trial excellent qualifications; and field trials excellent qualifications. The quality of the product showed that the group of students that learned to use Internet-based interactive multimedia higher than the group of students who learned with use of instructional media for text books.
\end{abstract}

Keywords: development of an interactive multimedia instructional media on the internet-based english language

\section{PENDAHULUAN}

Berdasarkan Kurikulum Tingkat Satuan

Pendidikan (KTSP), salah satu tujuan

pembelajaran Bahasa Inggris di SMP adalah mengembangkan kemampuan berkomunikasi dalam Bahasa Inggris dalam bentuk lisan maupun tulisan. Kemampuan berkomunikasi ini meliputi mendengarkan (listening), membaca (reading), dan menulis (writing). Dengan menggunakan beberapa jenis teks (genre) seperti transaksional, interpersonal, narrative, descriptive, recount, discussion dll.

Kemampuan berbahasa Inggris merupakan salah satu kemampuan yang sangat menentukan dalam memperoleh lapangan kerja akhir-akhir ini. Fenomena inilah yang mendasari munculnya berbagai macam kursus Bahasa Inggris di seluruh wilayah Indonesia. Terlepas dari bagaimana sesungguhnya mutu dari kursus-kursus Bahasa Inggris yang ada di Indonesia ini, tersirat suatu keadaan yang memprihatinkan yaitu kurang baiknya mutu hasil pengajaran Bahasa Inggris di sekolahsekolah. Tentu banyak kemunculan kursuskursus Bahasa Inggris bukan tanpa dasar, secara logika, kita dapat mengajukan argumentasi bahwa tidak mungkin kursus-kursus Bahasa Inggris sedemikian menjamurnya di Indonesia jika hasil pengajaran Bahasa Inggris di sekolah 
ternyata memuaskan. Jika demikian halnya, maka kursus Bahasa Inggris yang ada hanyalah yang ditujukan untuk kepentingan-kepentingan khusus seperti untuk memperoleh sertifikat TOEFL, IELTS, dan lain-lain serta bukan yang ditujukan untuk meningkatkan kemampuan berbahasa Inggris dalam kehidupan sehari-hari. Tapi kenyataannya, mayoritas kursus Bahasa Inggris yang ada adalah yang ditujukan untuk meningkatkan kemampuan berbahasa Inggris dalam kehidupan sehari-hari, bukan untuk tujuan-tujuan lain.

Beberapa pakar bahasa mendukung pandangan "semakin dini anak belajar bahasa asing, semakin mudah anak menguasai bahasa itu". Misalnya, McLaughlin dan Genesee menyatakan bahwa anak-anak lebih cepat memperoleh bahasa tanpa banyak kesukaran dibandingkan dengan orang dewasa. Demikian pula Eric H. Lennenberg, ahli neurologi (2009:116) berpendapat bahwa sebelum masa pubertas, daya pikir (otak) anak lebih lentur. Makanya, ia lebih mudah belajar bahasa. Sedangkan sesudahnya akan makin berkurang dan pencapaiannya pun tidak maksimal.

Penelitian yang dilakukan Fathman (2007:98) terhadap 200 anak berusia 6 - 15 tahun yang belajar Bahasa Inggris sebagai bahasa kedua di sekolah di AS, menunjukkan bahwa anak yg lebih muda (usia 6 - 10 tahun) lebih berhasil pada penguasaan fonologi (tata bunyi) Bahasa Inggris. Sedangkan pada anak lebih tua (11 - 15 tahun) lebih berhasil pada penguasaan morfologi (satuan bentuk bahasa terkecil) dan sintaksisnya (susunan kata dan kalimat).

Menurut Depdiknas dalam Kepmendiknas No. 22 Tahun 2006: Bahasa Inggris

merupakan alat untuk berkomunikasi secara lisan dan tulis. Berkomunikasi adalah memahami dan mengungkapkan informasi, pikiran, perasaan, dan mengembangkan ilmu pengetahuan, teknologi, dan budaya dengan menggunakan bahasa tersebut. Kemampuan berkomunikasi dalam pengertian yang utuh adalah kemampuan berwacana, yakni kemampuan memahami dan/atau menghasilkan teks lisan dan/atau tulis yang direalisasikan dalam empat keterampilan berbahasa, yaitu menyimak, berbicara, membaca dan menulis. Keempat keterampilan inilah yang digunakan untuk menanggapi atau menciptakan wacana dalam kehidupan bermasyarakat. Oleh karena itu, mata pelajaran Bahasa Inggris diarahkan untuk mengembangkan keterampilan- keterampilan tersebut agar lulusan mampu berkomunikasi dan berwacana dalam Bahasa Inggris pada tingkat literasi tertentu.

Menurut Azleen (2008:25) umumnya siswa merasa enggan mempelajari Bahasa

Inggris, bahkan ada yang takut atau merasa benci terhadap Bahasa Inggris. Hal ini berdampak negatif terhadap kualitas pembelajaran Bahasa Inggris di sekolah. Dampak isu negatif tentang Bahasa Inggris dapat mempengaruhi siswa dalam menentukan keberhasilan belajar Bahasa Inggris. Akibatnya muncul anggapan siswa bahwa Bahasa Inggris merupakan suatu bahasa yang sulit dipelajari dibanding dengan bahasa yang lain. Hal ini berarti dapat berakibat buruk terhadap hasil belajar Bahasa Inggris.

Menurut Sudjana \& Rivai (2001:2) mengatakan bahwa media pengajaran dapat mempertinggi proses belajar siswa dalam pengajaran yang pada gilirannya diharapkan dapat mempertinggi hasil belajar yang dicapainya. Alasannya berkenaan dengan manfaat media pengajaran dalam proses belajar siswa antara lain: (1) Pengajaran akan lebih menarik perhatian siswa sehingga dapat menumbuhkan motivasi belajar, (2) Bahan pengajaran akan lebih jelas maknanya sehingga akan lebih dipahami oleh para siswa dan memungkinkan siswa menguasai tujuan pengajaran lebih baik, (3) Metode mengajar akan lebih bervariasi, (4) Siswa lebih banyak melakukan kegiatan belajar sebab tidak hanya mendengarkan uraian guru tetapi juga aktivitas lain seperti mengamati, melakukan, mendemonstrasikan dan lain-lain. Salah satunya dengan menggunakan media pembelajaran berbasis multimedia yang disertai animasi.

Teknologi multimedia menggabungkan sepenuhnya teknologi komputer, sistem video dan sistem audio untuk mendapat kombinasi yang lebih baik dan meningkatkan interaksi di antara pemakai dengan komputer. Sajian audio dan visual pada pembelajaran multimedia menjadikan visualisasi lebih menarik. Tampilan multimedia akan membuat siswa lebih leluasa memilih, mensintesa dan mengelaborasi pengetahuan yang ingin dipahaminya. Multimedia juga menyediakan peluang bagi siswa untuk mengembangkan teknik pembelajaran sehingga menghasilkan hasil yang maksimal. Pembelajaran berbasis multimedia adalah pembelajaran menggunakan perangkat multimedia sebagai saran utamanya. Dalam hal ini komputer merupakan komponen utama dalam pembelajaran berbasis multimedia. 
Menurut Kusumah (2004:5) Komputer memberi kesempatan pada siswa untuk menyajikan input yang direspon komputer, atau sebaliknya. Dalam proses berikutnya respon dapat dijadikan sebagai stimulus baru sehingga dimungkinkan adanya respon lanjutan yang akan semakin memperkuat daya ingat siswa dalam konsep yang dipresentasikan. Input program dapat diciptakan secara beragam, demikian sehingga terarah pada pencapaian objektif pembelajaran.

Hasil pengamatan dari angket yang dilakukan pada Agustus 2012 diisi oleh 50 guru di SMP Chandra Kusuma Deliserdang menunjukkan bahwa $80 \%$ dari guru-guru membutuhkan media pembelajaran interaktif dalam proses pembelajaran agar proses pembelajaran berjalan lebih efektif. Dari hasil wawancara dengan guru Bahasa Inggris secara khusus menunjukkan bahwa masih menggunakan metode pembelajaran yang konvensional dan media yang sederhana sehingga siswa cenderung pasif selama pembelajaran. Mereka mengaku kesulitan memperoleh media pembelajaran yang efektif untuk pelajaran Bahasa Inggris di sekolah sehingga kegiatan pembelajaran kurang efektif dan peserta didik merasa kesulitan dalam memahami materi yang disampaikan. Dari angket yang disebar kepada 50 orang siswa yang diambil sebagai sampel, $100 \%$ siswa menyatakan membutuhkan media pembelajaran interaktif yang dapat mereka jadikan sebagai sarana pembelajaran secara individual. Siswa merasa jenuh dengan pola pembelajaran sekarang bahkan acuh terhadap pelajaran Bahasa Inggris sehingga tidak heran banyak siswa yang tidak memperhatikan penjelasan guru. Siswa pada umumnya enggan mengemukakan pertanyaan ataupun pendapat saat pembelajaran berlangsung. Rendahnya motivasi belajar siswa dalam pembelajaran Bahasa Inggris tersebut menyebabkan rendahnya hasil belajar Bahasa Inggris.

Media merupakan wadah dari pesan yang oleh sumber pesan ataupun penyalurnya ingin diteruskan kepada sasaran atau penerima pesan tersebut. Aplikasi

media pembelajaran berpijak pada kaidah ilmu komunikasi, yaitu "who says what in

which Channels to whom in what effect" Media pembelajaran berperan sebagai "wahana penyalur pesan atau informasi belajar sehingga mengkondisikan seseorang

untuk belajar". Secara umum media memiliki kegunaan yaitu: memperjelas pesan agar tidak terlalu verbalistis, mengatasi keterbatasan ruang, waktu tenaga dan daya indra, menimbulkan gairah belajar, interaksi lebih langsung antara murid dengan sumber belajar, memungkinkan anak belajar mandiri sesuai dengan bakat dan kemampuan visual, auditori \& kinestetiknya, memberi rangsangan yang sama, mempersamakan pengalaman \& menimbulkan persepsi yang sama.

Menurut Kemp \& Dayton (1985:43), kontribusi media dalam pembelajaran adalah : (1) penyampaian pembelajaran dapat lebih terstandar, (2) pembelajaran dapat

lebih menarik, (3) waktu penyampaian pembelajaran dapat diperpendek, (4) kualitas pembelajaran dapat ditingkatkan, (5) proses pembelajaran dapat berlangsung kapanpun dan dimanapun diperlukan, (6) sikap positif siswa terhadap materi pembelajaran serta proses pembelajaran dapat ditingkatkan, (7) peran guru berubah kearah yang positif.

$$
\text { Arsyad (2009:36-37) yang }
$$
menjelaskan, "multimedia interaktif ialah media berbasis komputer (pengajaran dengan bantuan komputer, interaktif video, hypertexts). Salah satu ciri dari media ini ialah bahwa ia membawa pesan atau informasi kepada penerima." Russell (2008:166) juga mencoba menjelaskan, "menciptakan multimedia, yang memadukan media seperti gambar, suara, dan gerakan untuk presentasi yang lebih lengkap. Peranti lunak presentasi, yang memadukan komputer dengan proyeksi video, bisa digunakan untuk presentasi." Sedangkan menurut Miarso (2009:464) berpendapat bahwa, "multimedia adalah berbagai media yang dapat dikombinasikan dengan teknologi lain dalam berbagai bentuk, multimedia ini merujuk kepada berbagai bahan ajar yang membentuk satu kesatuan unit yang terpadu (satu paket)."

Susilana (2009:126) juga menjelaskan, "tujuan multimedia interaktif sebagai bahan ajar adalah; (1) Memperjelas dan mempermudah penyajian pesan agar tidak terlalu bersifat verbalistis, (2) Mengatasi keterbatasan waktu, ruang, dan daya indera para siswa, (3) Dapat digunakan secara tepat dan bervariasi, seperti meningkatkan motivasi dan gairah belajar para siswa untuk menguasai materi pelajaran secara utuh, mengembangkan kemampuan siswa dalam berinteraksi langsung dengan lingkungan dan sumber belajar lainnya terutama bahan ajar yang berbasis ICT (Information and Communication Technology), memungkinkan siswa untuk belajar secara mandiri sesuai 
kemampuan dan minatnya. Dan memungkinkan para siswa untuk dapat mengukur atau mengevaluasi sendiri hasil belajarnya."

Pengembangan media pembelajaran interaktif berbasis internet pada mata pelajaran bahasa Inggris dalam standar kompetensi merespon makna yang terdapat dalam teks lisan fungsional pendek sederhana secara akurat, lancar, dan berterima untuk berinteraksi dengan lingkungan, menerapkan pola pembelajaran yang disajikan dalam bentuk model presentasi yang mengarahkan kita untuk mendesain pembelajaran yang digunakan sebagai pedoman dalam penyelenggaraan pembelajaran agar tercapai pembelajaran yang efektif, efesien, berdayaguna menarik dan humanis.

Dalam pengembangan media pembelajaran interaktif berbasis internet pada mata pelajaran bahasa Inggris penulis menggunakan model pengembangan Borg \& Gall (2005:7) dan untuk mengembangkan rencana pembelajarannya dipadukan dengan model pengembangan pembelajaran Dick \& Carey (2005:35). Model pengembangan Borg Dan Gall memuat panduan sistematika langkahlangkah yang dilakukan oleh peneliti agar produk yang dirancangnya mempunyai standar kelayakan. Yang diperlukan dalam pengembangan ini adalah rujukan tentang prosedur produk yang akan dikembangkan. Uraian model pengembangan Borg \& Gall, dijelaskan sebagai berikut; reset dan pengembangan bidang pendidikan (R\&D) adalah suatu proses yang digunakan untuk mengembangkan dan mengesahkan produk bidang pendidikan yang dikenal sebagai siklus $\mathrm{R} \& \mathrm{D}$, yang terdiri dari: pengkajian terhadap hasil-hasil penelitian sebelumnya yang berkaitan dengan validasi komponenkomponen pada produk yang akan dikembangkan, mengembangkannya menjadi sebuah produk, pengujian terhadap produk yang dirancang, dan peninjauan ulang dan mengoreksi produk tersebut berdasarkan hasil uji coba.

Tujuan dalam pengembangan ini adalah untuk: (1) menghasilkan media pembelajaran multimedia interaktif berbasis internet pada mata pelajaran bahasa inggris pada siswa memenuhi syarat sebagai media pembelajaran yang baik; (2) mengetahui efektivitas penggunaan media pembelajaran multimedia interaktif berbasis internet pada mata pelajaran bahasa inggris siswa.

\section{METODE PENELITIAN}

Penelitian ini dilaksanakan di SMP Swasta Chandra Kusuma kabupaten Deliserdang pada siswa kelas VIII. Model pengembangan merupakan serangkaian prosedur dalam rangka menghasilkan media pembelajaran pada matapelajaran bahasa Inggris Semester genap dengan standar kompetensi merespon makna yang terdapat dalam teks lisan fungsional pendek sederhana secara akurat, lancar, dan berterima untuk berinteraksi dengan lingkungan oleh siswa. Model pengembangan yang dipakai merupakan adaptasi dari model pengembangan Borg \& Gall (2005) dan untuk mengembangkan rencana pembelajarannya dipadukan dengan model pengembangan pembelajaran Dick \& Carey (2005).

Prosedur pengembangan yang ditempuh untuk menghasilkan produk multimedia interaktif dibagi menjadi 6 tahap, yaitu: (1) Tahap pertama melakukan penelitian pendahuluan, (2) tahap kedua pembuatan desain software, (3) tahap ketiga pengumpulan data, (4) tahap keempat membuat dan memproduksi multimedia interaktif, (5) tahap kelima yaitu review atau uji lapangan dalam rangka evaluasi formatif dan revisi produk. Evaluasi formatif terus berlangsung selama proses pengembangan mulai dari tahap analisis, desain produksi maupun implementasi sampai diperoleh hasil yang sesuai dengan tujuan yang telah ditetapkan, dan (6) uji keefektifan produk.

Analisis data dilakukan untuk memperoleh pemahaman konkret tentang keberhasilan media pembelajaran multimedia interaktif berbasis internet mata pelajaran bahasa inngris yang sudah diproduksi. Hasil yang diperoleh digunakan sebagai bahan pertimbangan dalam memperbaiki produk. Analisis data dalam penelitian ini menggunakan analisis deskriptif dan analisis uji t.

\section{HASIL DAN PEMBAHASAN Hasil}

Prosedur aplikasi pengembangan media pembelajaran multimedia interaktif berbasis internet ini dilaksanakan secara bertingkat. Prosedur pertama pada pelaksanaan pengembangan ini yaitu mengadakan analisis kebutuhan dengan cara menebar angket kepada 50 guru dan 50 siswa tersebut dengan metode menguraikan defenisi dari media pembelajaran multimedia interaktif berbasis internet pada angket agar responden memiliki gambaran tentang pertanyaan dalam angket yang 
disampaikan. Hasil pelaksanaan dari penyebaran angket didapatkan bahwa $80 \%$ dari guru-guru mengatakan membutuhkan media pembelajaran multimedia interaktif berbasis internet sehingga proses pembelajaran berjalan lebih efektif, dan 100\% siswa mengatakan membutuhkan media pembelajaran multimedia interaktif berbasis internet supaya dapat mereka jadikan sebagai sarana pembelajaran secara individual. Hasil data analisis kebutuhan tersebut ditampilkan pada Tabel 1.

Tabel 1. Data Analisis Kebutuhan

\begin{tabular}{|c|c|c|c|c|c|c|}
\hline \multirow[t]{2}{*}{ No } & \multirow[t]{2}{*}{ Jenis Informasi } & \multirow{2}{*}{$\begin{array}{c}\text { Jawa } \\
\text { ban }\end{array}$} & \multicolumn{4}{|c|}{ Frekuensi } \\
\hline & & & Guru & Siswa & Jumlah & Persentase \\
\hline \multirow[t]{2}{*}{1} & \multirow{2}{*}{$\begin{array}{l}\text { Telah mengenal } \\
\text { multimedia interaktif } \\
\text { berbasis internet }\end{array}$} & $\mathrm{Ya}$ & 10 & 8 & 18 & $18 \%$ \\
\hline & & Tidak & 40 & 42 & 82 & $82 \%$ \\
\hline \multirow[t]{2}{*}{2} & \multirow{2}{*}{$\begin{array}{l}\text { Menggunakan } \\
\text { multimedia interaktif } \\
\text { berbasis internet dalam } \\
\text { proses pembelajaran }\end{array}$} & $\mathrm{Ya}$ & 4 & 7 & 11 & $11 \%$ \\
\hline & & Tidak & 46 & 43 & 89 & $89 \%$ \\
\hline \multirow[t]{2}{*}{3} & \multirow{2}{*}{$\begin{array}{l}\text { Keperluan akan } \\
\text { multimedia interaltif } \\
\text { berbasis internet dalam } \\
\text { proses pembelajaran }\end{array}$} & $\mathrm{Ya}$ & 41 & 39 & 80 & $80 \%$ \\
\hline & & Tidak & 9 & 11 & 20 & $20 \%$ \\
\hline
\end{tabular}

Uji coba lapangan dilakukan terhadap siswa yang terdiri dari 58 siswa. Uji coba lapangan menghasilkan data-data yang nantinya akan mengukur kelayakan dari produk yang dikembangkan, serta untuk mengetahui bagaimana manfaat produk tersebut bagi pemakainya. Hasil evaluasi terhadap multimedia interaktif pada aspek kualitas materi pembelajaran dapat dilihat pada Tabel 2. Tabel 2 menunjukkan hasil tanggapan siswa pada aspek kualitas materi pembelajaran untuk uji coba lapangan dan keseluruhannya dalam kriteria "Sangat Baik".

Tabel 2. Skor Penilaian Multimedia Interaktif Berbasis Internet Mata Pelajaran Bahasa Inggris Pada Uji Coba Lapangan Tentang Kualitas Materi Pembelajaran

\begin{tabular}{|c|c|c|c|c|c|c|c|c|}
\hline \multirow[t]{2}{*}{ No } & \multirow[t]{2}{*}{ Indikator Penilaian } & \multicolumn{5}{|c|}{ Skor } & \multirow[t]{2}{*}{ Rata-rata } & \multirow[t]{2}{*}{ Kriteria } \\
\hline & & 1 & 2 & 3 & 4 & 5 & & \\
\hline 1 & Kesesuaian materi & & & & 6 & 52 & $97,93 \%$ & Sangat Baik \\
\hline 2 & $\begin{array}{l}\text { Kejelasan petunjuk } \\
\text { belajar }\end{array}$ & & & & 3 & 55 & $98,97 \%$ & Sangat Baik \\
\hline 3 & $\begin{array}{l}\text { Kemudahan memahami } \\
\text { kalimat pada teks }\end{array}$ & & & & 13 & 45 & $95,52 \%$ & Sangat Baik \\
\hline 4 & $\begin{array}{l}\text { Kemudahan memahami } \\
\text { pembelajaran }\end{array}$ & & & & 10 & 48 & $96,55 \%$ & Sangat Baik \\
\hline 5 & $\begin{array}{l}\text { Ketepatan urutan } \\
\text { penyajian }\end{array}$ & & & & 5 & 53 & $98,28 \%$ & Sangat Baik \\
\hline 6 & Kecukupan latihan & & & & 13 & 45 & $95,52 \%$ & Sangat Baik \\
\hline 7 & Kejelasan umpan balik & & & & & 58 & $100,00 \%$ & Sangat Baik \\
\hline 8 & $\begin{array}{l}\text { Bantuan belajar dengan } \\
\text { program }\end{array}$ & & & & & 58 & $100,00 \%$ & Sangat Baik \\
\hline \multicolumn{7}{|c|}{ Rata-rata } & $97,84 \%$ & Sangat Baik \\
\hline
\end{tabular}


Hasil evaluasi terhadap multimedia interaktif berbasis internet pada aspek kualitas teknis/tampilan dapat dilihat pada Tabel 3. Tabel 3 menunjukkan hasil tanggapan siswa pada aspek teknik/tampilan untuk uji coba lapangan dan keseluruhannya dalam kriteria "Sangat Baik".

Tabel 3. Skor Penilaian Multimedia Interaktif Berbasis Internet Mata Pelajaran Bahasa Inggris Pada Uji Coba Lapangan Tentang Kualitas Teknis/Tampilan

\begin{tabular}{|c|l|c|c|c|c|c|c|c|}
\hline No & \multirow{2}{*}{ Indikator Penilaian } & \multicolumn{5}{|c|}{ Skor } & Rata-rata & Kriteria \\
\cline { 3 - 8 } & & $\mathbf{1}$ & $\mathbf{2}$ & $\mathbf{3}$ & $\mathbf{4}$ & $\mathbf{5}$ & & \\
\hline 1 & Keindahan tampilan layar & & & & & 58 & $100,00 \%$ & Sangat Baik \\
\hline 2 & Keterbacaan teks & & & & & 58 & $100,00 \%$ & Sangat Baik \\
\hline 3 & $\begin{array}{l}\text { Kualitas gambar dan } \\
\text { animasi }\end{array}$ & & & & 5 & 53 & $98,28 \%$ & Sangat Baik \\
\hline 4 & Komposisi wama & & & & 15 & 43 & $94,83 \%$ & Sangat Baik \\
\hline 5 & Navigasi & & & & 9 & 49 & $86,67 \%$ & Sangat Baik \\
\hline 6 & Daya dukung musik & & & & 8 & 50 & $97,24 \%$ & Sangat Baik \\
\hline 7 & Interaksi & & & & 2 & 56 & $99,31 \%$ & Sangat Baik \\
\hline \multicolumn{7}{|c|}{ Rata-rata } \\
\hline
\end{tabular}

Hasil penilaian uji coba lapangan terhadap aspek kualitas materi pembelajaran dan kualitas teknis/tampilan pada multimedia interaktif berbasis internet pada mata pelajaran bahasa inggris dirangkum pada Tabel 3 dan $100 \%$ menyatakan "Sangat Baik".

Tabel 4. Tingkat Kecenderungan Penilaian Terhadap Aspek Kualitas Materi Pembelajaran Multimedia Interaktif Berbasis Internet Pada Mata Pelajaran Bahasa Inggris Pada Uji Lapangan

\begin{tabular}{|c|c|c|c|c|}
\hline No & Kategorisasi & Rentang Skor & Frekuensi & Persentase \\
\hline 1 & Sangat baik & $81 \% \leq \mathrm{X} \leq 100 \%$ & 58 & $100 \%$ \\
\hline 2 & Baik & $61 \% \leq \mathrm{X} \leq 80 \%$ & 0 & $0 \%$ \\
\hline 3 & Sedang & $41 \% \leq x \leq 60 \%$ & 0 & $0 \%$ \\
\hline 4 & Kurang Baik & $21 \% \leq \mathrm{X} \leq 40 \%$ & 0 & $0 \%$ \\
\hline 5 & Sangat kurang & $0 \% \leq \mathrm{x} \leq 20 \%$ & 0 & $0 \%$ \\
\hline \multicolumn{3}{|c|}{ Jumlah } & 58 & $100 \%$ \\
\hline
\end{tabular}

Tabel 5. Tingkat Kecenderungan Penilaian Terhadap Aspek Kualitas Teknis/Tampilan Multimedia Interaktif Berbasis Internet Pada Mata Pelajaran Bahasa Inggris Pada Uji Lapangan

\begin{tabular}{|c|l|c|c|c|}
\hline No & Kategorisasi & Rentang Skor & Frekuensi & Persentase \\
\hline 1 & Sangat baik & $81 \% \leq \mathrm{X} \leq 100 \%$ & 58 & $100 \%$ \\
\hline 2 & Baik & $61 \% \leq \mathrm{X} \leq 80 \%$ & 0 & $0 \%$ \\
\hline 3 & Sedang & $41 \% \leq \mathrm{X} \leq 60 \%$ & 0 & $0 \%$ \\
\hline 4 & Kurang Baik & $21 \% \leq \mathrm{X} \leq 40 \%$ & 0 & $0 \%$ \\
\hline 5 & Sangat kurang & $0 \% \leq \mathrm{X} \leq 20 \%$ & 0 & $0 \%$ \\
\hline \multicolumn{2}{|r|}{ Jumlah } & $\mathbf{5 8}$ & $\mathbf{1 0 0} \%$ \\
\hline
\end{tabular}


Pada uji coba lapangan pada siswa ternyata secara umum siswa menyatakan bahwa multimedia interaktif berbasis internet yang dikembangkan sangat baik, dan tidak terdapat masalah yang harus diperbaiki. Dengan demikian tidak akan diadakan revisi IV pada tahap uji coba lapangan, yang juga berarti multimedia interaktif berbasis internet telah siap untuk diuji keefektifannya.

Analisis Data Hasil Uji Coba Tahap II

Uji Coba Lapangan Tabel 6 berikut menunjukkan persentase rata-rata hasil penilaian pada uji coba lapangan terhadap aspek kualitas materi pembelajaran sebesar 97,84\% dan aspek kualitas teknis atau tampilan sebesar 98,08 \% dan masing-masing termasuk kategori sangat baik. Berdasarkan hasil penilaian pada multimedia interaktif berbasis internet pada mata pelajaran bahasa inggris pada uji coba lapangan tidak terdapat saran perbaikan.

Tabel 6. Persentase Rata-Rata Hasil Penilaian Terhadap Multimedia Interaktif Berbasis Internet Pada Mata Pelajaran Bahasa Inggris Pada Uji Coba Lapangan

\begin{tabular}{|c|l|c|c|}
\hline No & \multicolumn{1}{|c|}{ Kategorisasi } & $\begin{array}{c}\text { Persentase } \\
\text { Rata-rata }\end{array}$ & Kriteria \\
\hline 1 & Kualitas materi pembelajaran & $97,84 \%$ & Sangat Baik \\
\hline 2 & Kualitas teknis/tampilan & $98,08 \%$ & Sangat Baik \\
\hline \multicolumn{2}{|c|}{ Rata-rata } & $97,96 \%$ & Sangat Baik \\
\hline
\end{tabular}

Berdasarkan hasil perhitungan pada tabel diatas diperoleh output thitung sebesar

3,285 dan ttabel sebesar 1,67 pada taraf kepercayaan 95\%. Maka diperoleh bahwa thitung > ttabel atau 3,285 > 1,67 atau dengan kata lain Ho ditolak dan Ha diterima.

Berdasarkan data-data di atas maka disimpulkan bahwa hasil belajar siswa pada mata

pelajaran bahasa inggris yang diajar dengan menggunakan multimedia interaktif berbasis internet lebih tinggi dari siswa yang diajar dengan pembelajaran konvensional teruji kebenarannya. Hal ini berarti hasil belajar siswa yang menggunakan multimedia interaktif berbasis internet lebih tinggi dari hasil belajar siswa yang diajar dengan pembelajaran konvensional dengan efektifitas penggunaan multimedia interaktif berbasis internet sebesar $80,46 \%$. Nilai keefektifan multimedia interaktif berbasis internet ini lebih tinggi dari nilai keefektifan pembelajaran konvensional yaitu sebesar $71,72 \%$.

\section{Pembahasan}

Pembahasan Hasil Penelitian Pengembangan Produk Produk pengembangan multimedia interaktif berbasis internet pada mata pelajaran bahasa inggris merupakan materi pembelajaran yang telah dikembangkan dengan memperhatikan aspek pembelajaran dan media sebagai prinsip desain pesan pembelajaran. Penelitian pengembangan produk yang dilakukan ini diarahkan untuk menghasilkan suatu produk berupa multimedia interaktif berbasis internet pada mata pelajaran bahasa inggris yang digunakan untuk meningkatkan proses pembelajaran maupun kompetensi siswa. Oleh sebab itu proses penelitian ini dilakukan dan diawali dengan, (1) Tahap pertama melakukan penelitian pendahuluan, (2) tahap kedua pembuatan desain software, (3) tahap ketiga pengumpulan data, (4) tahap keempat membuat dan memproduksi multimedia interaktif, (5) tahap kelima yaitu review atau uji lapangan dalam rangka evaluasi formatif dan revisi produk. Evaluasi formatif terus berlangsung selama proses pengembangan mulai dari tahap analisis, desain produksi maupun implementasi sampai diperoleh hasil yang sesuai dengan tujuan yang telah ditetapkan, dan (6) uji keefektifan produk.

Beberapa kegunaan dan manfaat dalam penggunaan multimedia interaktif berbasis internet pada mata pelajaran bahasa inggris sebagai berikut: (1) materi mudah dipahami karena konsep yang disajikan direncanakan untuk mempermudah siswa dan sistematis, (2) multimedia interaktif berbasis internet memberi kesempatan pada siswa untuk belajar sesuai dengan kecepatan masingmasing individu, (3) belajar lebih cepat dan menarik sehingga tidak menimbulkan kebosanan karena dilengkapi dengan gambar-gambar dan animasi serta soal 
latihan dan tes, (4) multimedia interaktif berbasis internet ini juga dapat digunakan sebagai alternatif media pembelajaran secara konvensional maupun individu.

Pembahasan Hasil Penelitian Uji Keefektifan Produk terdapat perbedaan hasil belajar mata pelajaran bahasa inggris antara siswa yang dibelajarkan dengan menggunakan multimedia interaktif berbasis internet dan siswa yang dibelajarkan tanpa menggunakan multimedia interaktif berbasis internet yaitu rata-rata hasil belajar siswa yang dibelajarkan dengan menggunakan multimedia interaktif berbasis internet lebih tinggi dibandingkan dengan siswa yang dibelajarkan tanpa menggunakan multimedia interaktif berbasis internet. Hal ini dapat dilihat dari hasil nilai rata-rata siswa yang diajar dengan multimedia interaktif berbasis internet, sedangkan hasil nilai rata-rata siswa yang diajar tanpa menggunakan multimedia interaktif berbasis internet .

Dari data ini membuktikan bahwa penggunaan multimedia interaktif berbasis internet lebih baik dalam meningkatkan kompetensi dan pengetahuan siswa pada mata pelajaran bahasa inggris daripada tanpa menggunakan multimedia interaktif berbasis internet.

Penggunaan multimedia interaktif berbasis internet memungkinkan siswa untuk lebih mudah memahami materi karena dari multimedia interaktif berbasis internet ini memungkinkan siswa untuk berinteraksi langsung, memiliki gambargambar, animasi background dan soal yang hasilnya dapat langsung diketahui siswa dan guru. Selain itu, multimedia interaktif berbasis internet ini sangat praktis, karena dapat dibawa oleh siswa dan dapat dipelajari dirumah. Multimedia interaktif berbasis internet ini juga dapat menguji kemampuan dan pemahaman siswa secara langsung melalui tes atau soal-soal latihan.

Walaupun dalam penelitian ini diperoleh data bahwa hasil belajar mata pelajaran bahasa inggris siswa lebih tinggi jika dibelajarkan dengan menggunakan multimedia interaktif berbasis internet dari pada hasil belajar siswa yang dibelajarkan tanpa menggunakan multimedia interaktif berbasis internet, namun dalam pelaksanaannya kedua media pembelajaran ini telah mampu meningkatkan pemahaman dan hasil belajar siswa. Keefektifan penggunaan multimedia interaktif berbasis internet ini adalah sebesar
$80,46 \%$ dan tanpa media adalah sebesar 71,72 $\%$.

\section{PENUTUP \\ Simpulan}

Berdasarkan rumusan, tujuan, hasil dan pembahasan enelitian pengembangan

multimedia interaktif berbasis internet yang dikemukakan sebelumnya maka dapat disimpulkan sebagai berikut :

1) Hasil validasi dari ahli materi terhadap multimedia interaktif berbasis internet pada mata pelajaran bahasa inggris yang dikembangkan menunjukkan bahwa; (1) kualitas materi pembelajaran dinilai sangat baik, (2) kualitas strategi pembelajaran dinilai sangat baik, dan (3) kualitas sistem penyampaian pembelajaran dinilai sangat baik. Dengan demikian multimedia interaktif berbasis internet pada mata pelajaran bahasa inggris yang dikembangkan secara keseluruhan termasuk dalam kategori "Sangat Baik".

2) Hasil validasi dari ahli desain pembelajaran terhadap multimedia interaktif berbasis internet pada mata pelajaran bahasa inggris yang dikembangkan menunjukkan bahwa; (1) kualitas desain pembelajaran dinilai sangat baik, (2) kualitas desain informasi dinilai sangat baik, (3) kualitas desain interaksi dinilai sangat baik, dan (4) kualitas desain presentasi dinilai sangat baik. Dengan demikian multimedia interaktif berbasis internet pada mata pelajaran bahasa inggris yang dikembangkan secara keseluruhan termasuk dalam kategori "Sangat Baik".

3) Hasil validasi dari ahli rekayasa perangkat lunak terhadap multimedia interaktif berbasis internet pada mata pelajaran bahasa inggris yang dikembangkan menunjukkan bahwa; (1) kualitas pemrograman dinilai sangat baik, dan (2) kualitas teknis/tampilan dinilai sangat baik. Dengan demikian multimedia interaktif berbasis internet pada mata pelajaran bahasa inggris yang dikembangkan secara keseluruhan termasuk dalam kategori "Sangat Baik".

4) Menurut tanggapan dari siswa pada uji coba perorangan terhadap multimedia interaktif berbasis internet pada mata pelajaran bahasa inggris yang dikembangkan menunjukkan bahwa; (1) kualitas materi pembelajaran dinilai sangat baik, dan (2) kualitas teknis/tampilan dinilai sangat baik. Dengan demikian multimedia interaktif berbasis internet pada mata pelajaran bahasa inggris 
yang dikembangkan secara keseluruhan termasuk dalam kategori "Sangat Baik".

5) Menurut tanggapan dari siswa pada uji coba kelompok kecil terhadap multimedia interaktif berbasis internet pada mata pelajaran bahasa inggris yang dikembangkan menunjukkan bahwa; (1) kualitas materi pembelajaran dinilai sangat baik, dan (2) kualitas teknis/tampilan dinilai sangat baik. Dengan demikian multimedia interaktif berbasis internet pada mata pelajaran bahasa inggris yang dikembangkan secara keseluruhan termasuk dalam kategori "Sangat Baik".

6) Menurut tanggapan dari siswa pada uji coba Lapangan terhadap multimedia interaktif berbasis internet pada mata pelajaran bahasa inggris yang dikembangkan menunjukkan bahwa; (1) kualitas materi pembelajaran dinilai sangat baik, dan (2) kualitas teknis/tampilan dinilai sangat baik. Dengan demikian multimedia interaktif berbasis internet pada mata pelajaran bahasa inggris yang dikembangkan secara keseluruhan termasuk dalam kategori "Sangat Baik".

7) Multimedia interaktif berbasis internet yang dikembangkan layak digunakan sebagai media pembelajaran mata pelajaran bahasa inggris untuk siswa, karena memiliki nilai ratarata yang lebih tinggi dari nilai media skala Likert.

8) Tes hasil belajar siswa terhadap penggunaan multimedia interaktif berbasis internet yang dikembangkan menunjukkan bahwa kelas eksperimen lebih tinggi dari menggunakan buku teks; kelas kontrol. Dengan demikian disimpulkan bahwa terdapat perbedaan yang signifikan antara hasil belajar siswa yang dibelajarkan dengan menggunakan multimedia interaktif berbasis internet dengan buku teks,

9) Multimedia interaktif berbasis internet yang dikembangkan memiliki keefektifan sebesar $80,46 \%$ lebih tinggi dari keefektifan buku teks sebesar $71,72 \%$.

\section{Saran}

Berdasarkan hasil temuan yang telah diuraikan pada kesimpulan serta implikasi hasil penelitian, maka berikut ini diajukan beberapa saran yaitu :

a. Multimedia interaktif berbasis internet pada mata pelajaran bahasa inggris ini adalah alat untuk membantu dalam proses penyampaian materi pembelajaran maka dari itu keberadaan guru masih sangat diperlukan sebagai fasilitator dan siswa tetap terlibat aktif dalam proses pembelajaran.

b. Agar hasil produk lebih maksimal dan layak digunakan lebih jauh lagi, maka diperlukan pengembang yang terdiri dari : ahli pengembang kurikulum, ahli bidang studi \& ahli materi, ahli media, dukungan dana, sarana \& waktu, dan kemampuan saranaprasarana dalam produksi media yang memadai.

\section{DAFTAR PUSTAKA}

AECT. (1977). The Definition of Educational Technology. Washington,DC: AECT.

Arsyad, Azhar. (1997). Media Pengajaran. Jakarta : Raja Grafindo Persada.

Borg, W. \&V Gall, M.D. (1983). Educational Research. An Introduction (4th Edition). New York \& London : Longman.

Brandie Colon, Key Ann Taylor \& Jerry Willis. (2000). Constructivist Instructional Design: Creating Multimedia Package For Teaching Critical Qualitative Research. The Qualitative Report, Volume 5, Number 1 \& 2, May 2000. New York \& London : Longman.

Budiningsih, Asri. (2003). Desain Pesan Pembelajaran. Yogyakarta : Fakultas Ilmu Pendidikan Universitas Negeri Yogyakarta.

Dedeng, I Nyoman Sudana. (1989). Ilmu Pengajaran Taksonomi Variabel. Jakarta: PPLPTK, DEPDIKBUD.

Dick, W. \& Cary, L. (2005). The Systematic Design Of Instruction. United States of America : Scott Foresman and Company.

Djamarah \& Zein. (2006). Strategi Belajar Mengajar. Jakarta: Rineka Cipta.

Gagne, Robert M \& Briggs, Leslie J. (1979). Principles of Instructional Design (2 ${ }^{\text {nd }}$ Edition). New York : Holt, Rinehart and Winston.

Hacbart, Steven. (1996). The Educational Technology Hand Book. New Jersey: Educational Technology Publications, Inc.

Heinich, Robert, et. Al. (1996). Instructional Media And Technologies For Learning (5th Edition). New Jersey : A Simon \& Schuster Company Angelwood Cliffs.

Himpunan Peraturan Perundang-undangan. (2005). Standar Nasional Pendidika $(S N P)$. Bandung : Fokus Media.

Hornby, A.S. (1985). Oxford Advanced Learner's Dictionary Of Current English. Oxford USA : Oxford University Press. 
(2003). Teknik Jitu Menguasai Macromedia Flash MX 2004. Jakarta: Elex Media Komputindo.

Kemp. (1994). Design Effective Instruction. New York: MacMillan College Publishing Company.

M. Ngalim, Purwanto. (1990), Psikologi Pendidikan, Bandung: Remaja Rosdakarya.

Mulyasa. (2007), Kurikulum Tingkat Satuan Pendidikan, Bandung: PT Remaja Rosdakarya.

Ngalimun. (2012). Strategi dan Model Pembelajaran. Banjarmasin: Scripta Cendekia.

R.E, Slavin. (2000). Educational Psychology: Theory and Practice. 6th Edition. Boston: Allyn and Bacon.

Ron, Philips. (1997). Multimedia Interactive. Boston : Kogan Page.

Romiszowski. (1988). The Selection and Use of Instructional Media. United States: Nichols Publishing.

Slameto. (2003). Belajar dan Faktor-Faktor yang Mempengaruhinya. Jakarta: Rhineka Cipta.
Sleeman, Philip. J. (1979). Instructional Media and Technology. New York: Longman Inc.

Sadiman, Arif \& dkk. (1986). Media Pendidikan, Pengertian, Pengembangan dan Pemanfaatannya. Jakarta : Pustekkom Dikbud.

Sudjana, Nana. (1989). Cara Belajar Siswa Aktif-Dalam Proses Belajar Mengajar. Bandung: Sinar Baru.

Sudjana, Nana. (2004). Penilaian Hasil Proses Belajar Mengajar. Bandung: osdakarya.

Sudjana. (2005). Media Pengajaran. Bandung : Sinar Baru Algensindo.

Thoha, M. Chabib. (1991). Teknik Evaluasi Pendidikan . Jakarta: Rajawali.

Uno, B. Hamzah. (2005). Orientasi Baru dalam Psikologi Pembelajaran, Jakarta: PT. Bumi Aksara.

Waldopo. (2002). Penelitian dan Pengembangan, Pendekatan Dalam Mengembangkan Produk-Produk di Bidang Pendidikan Pembelajaran. Jakarta: Pustekkom. 